
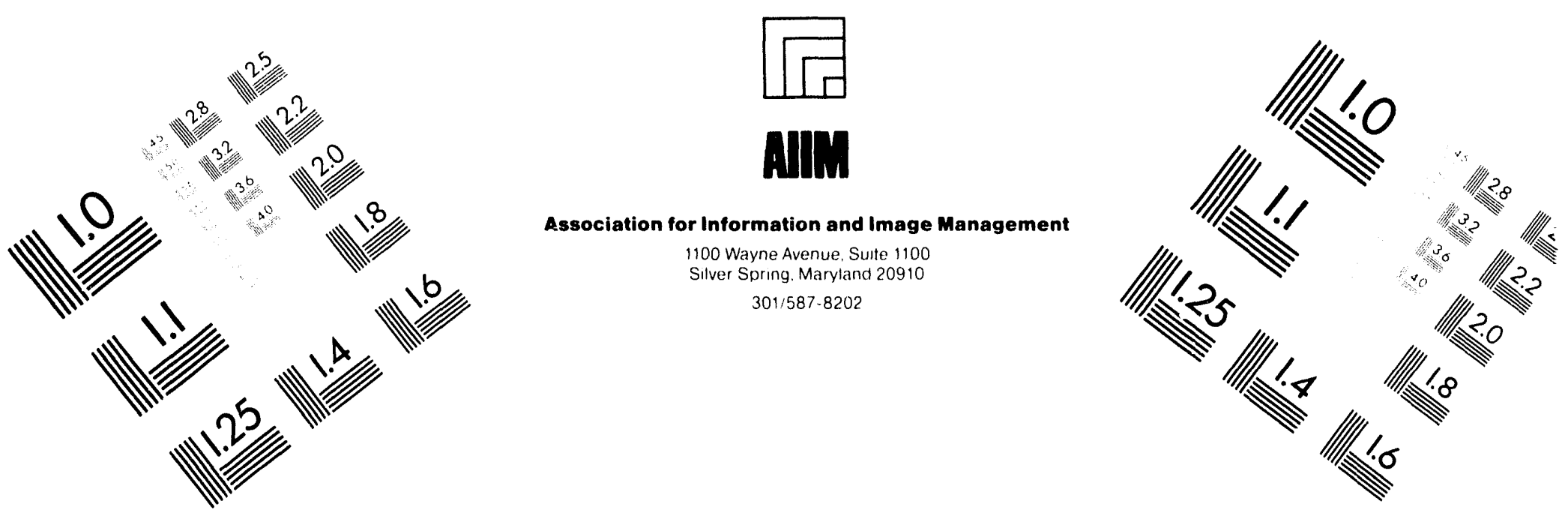

\title{
Centimeter
}

1
$\mid$
$\mid$ Inches
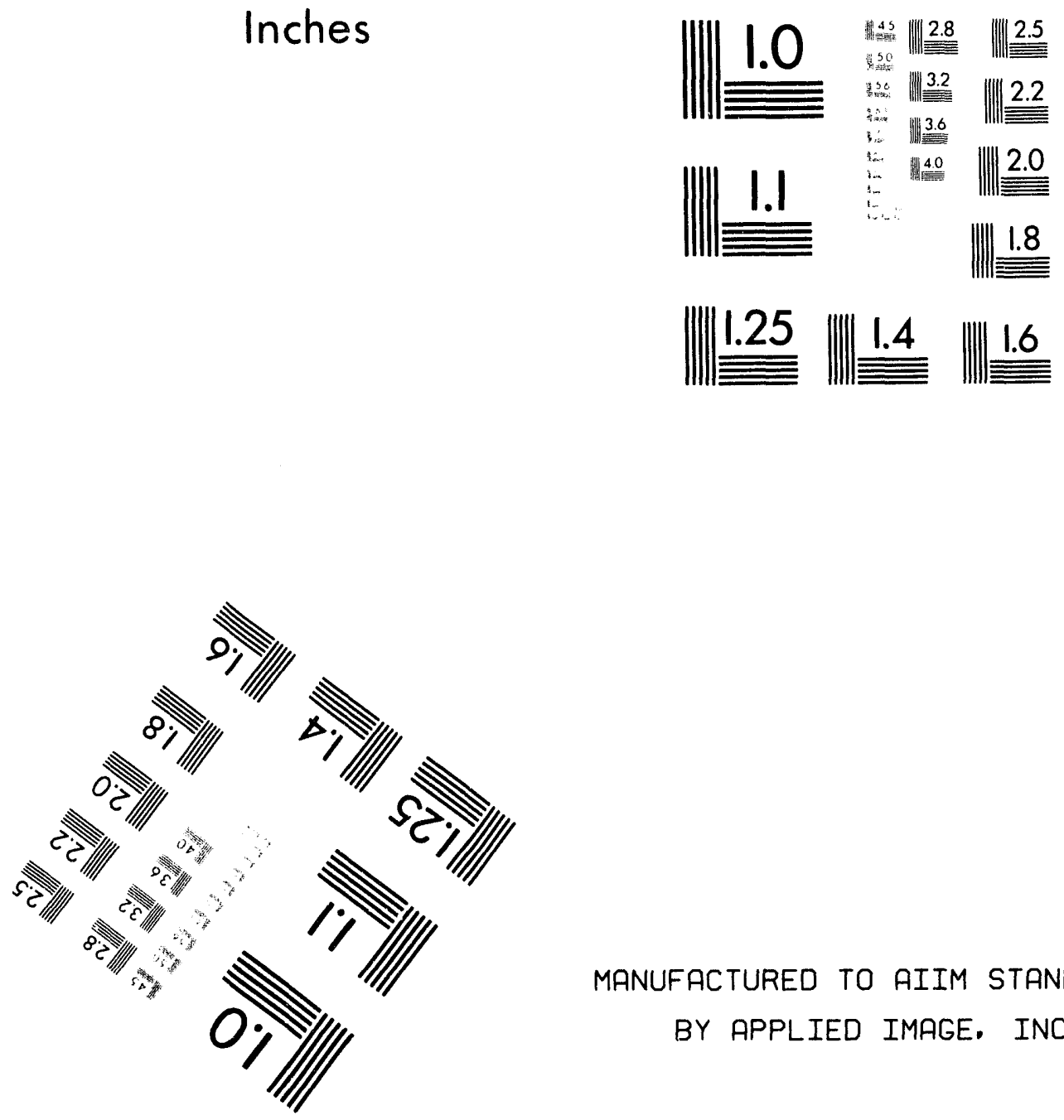

MANUFACTURED TO AIIM STANDARDS

BY APPLIED IMAGE. INC.

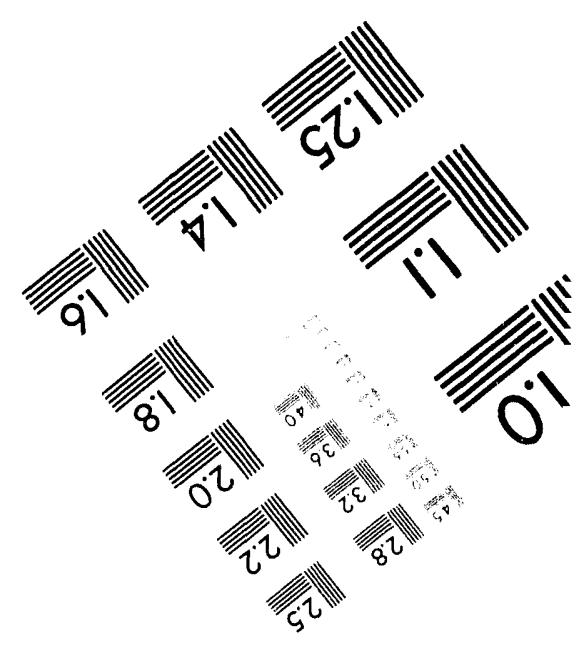



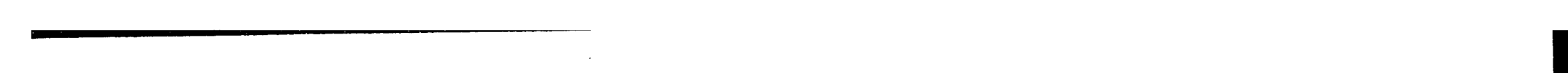

.
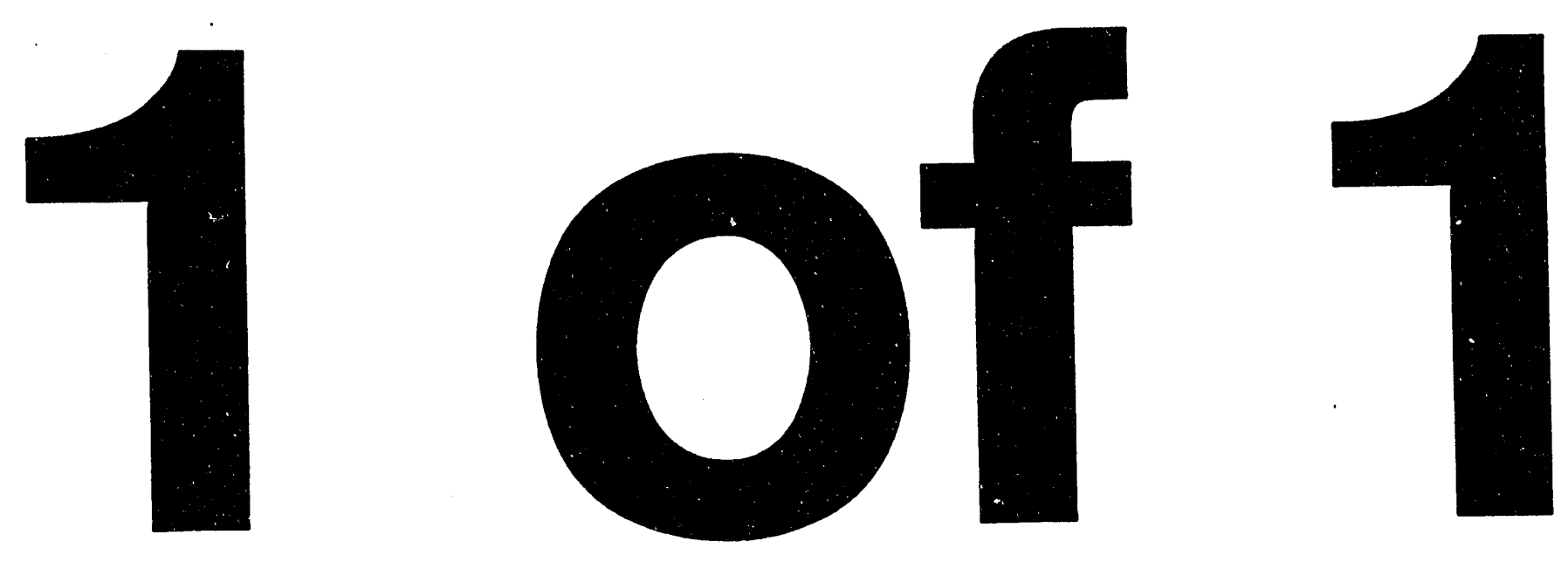

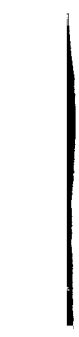


PNL-9057

UC-310

\section{Impact Evaluation of an Induction Furnace Replacement Under the Energy \$avings Plan at Mackenzie Specialty Castings, Incorporated}

M. A. Oens

G. E. Spanner

April 1994

Prepared for Sheila Riewer

Program Evaluation Section

Office of Energy Resources

Bonneville Power Administration

U.S. Department of Energy

under Contract DE-AC06-76RLO 1830

Pacific Northwest Laboratory

Richland, Washington 99352 


\section{DISCLAIMER}

This report was prepared as an account of work sponsored by an agency of the United States Government. Neither the United States Government nor any agency thereof, nor Battelle Memorial Institute, nor any of their employees, makes any warranty, expressed or implied, or assumes any legal liability or responsibility for the accuracy, completeness, or usefulness of any information, apparatus, product, or process disclosed, or represents that its use would not infringe privately owned rights. Reference herein to any specific commercial product, process, or service by trade name, trademark, manufacturer, or otherwise does not necessarily constitute or imply its endorsement, recommendation, or favoring by the United States Government or any agency thereof, or Battelle Memorial institute. The views and opinions of authors expressed herein do not necessarily state or reflect those of the United States Government or any agency thereof.

\section{PACIFIC NORTHWEST LABORATORY}

operated by

BATTELLE MEMORIAL INSTITUTE

for the

UNITED STATES DEPARTMENT OF ENERGY under Contract DE-ACO6-76RLO 1830 


\section{Summary}

This impact evaluation of in induction furnace replacement that was recently installed at Mackenzie Specialty Castings, Incorporated (Mackenzie Castings) was conducted for the Bonneville Power Administration (Bonneville) as part of an evaluation of its Energy \$avings Plan (E\$P) Program. The project cunsists of replacing old power supplies and induction furnace with new, more efficient supplies and equipment. The objective of this impact evaluation was to assess how much electrical energy is being saved at Mackenzie Castings as a result of the E\$P and to determine how much the savings cost Bonneville and the region. The impact of the project was evaluated with a combination of engineering analysis, financial analysis, interviews, and submittal reviews (Mackenzie Castings's proposal and completion report).

Based on this impact evaluation, energy savings from this project are expected to be 425,257 $\mathrm{kWh} / \mathrm{yr}$ at minimum annual production, $647,037 \mathrm{kWh} / \mathrm{yr}$ at typical annual production, and 1,294,074 $\mathrm{kWh} / \mathrm{yr}$ at maximum annual production, or $0.05,0.07$, and 0.15 average megav/atts, respectively. On a per-ton basis, this project will save $608 \mathrm{kWh} /$ ton or $31 \%$ at minimum production and $431 \mathrm{kWh} /$ ton or $39 \%$ at typical and maximum production. The project cost $\$ 277,110$ to install, and Mackenzie Castings received payment of $\$ 102,551$ (in 1993 dollars) from Bonneville for acquisition of the energy savings. The real levelized cost of these energy savings to Bonneville is 22.9 mills $/ \mathrm{kWh}$ at minimum production, $15.1 \mathrm{mills} / \mathrm{kWh}$ typical production, and $7.5 \mathrm{mills} / \mathrm{kWh}$ at maximum production (in 1993 dollars) over the project's assumed 15-year life. The real levelized cost to the region is $59.1 \mathrm{mills} / \mathrm{kWh}$ at minimum production, $38.8 \mathrm{mills} / \mathrm{kWh}$ at typical production, and $19.4 \mathrm{mills} / \mathrm{kWh}$ at maximum production in 1993 dollars, not including transmission and distribution effects.

Based on interviews with Mackenzie Castings management, it was determined that this project would not have been implemented without the E\$P acquisition payment from Bonneville. 


\section{Contents}

Summary $\ldots \ldots \ldots \ldots \ldots \ldots \ldots \ldots \ldots \ldots \ldots \ldots \ldots \ldots \ldots \ldots$ ii

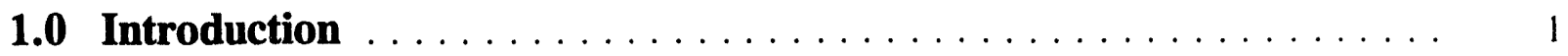

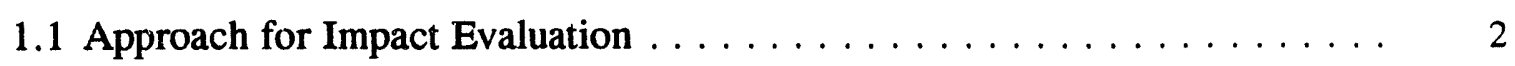

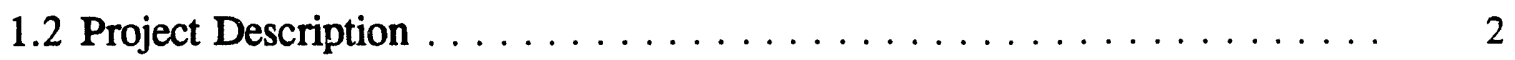

1.3 Summary of Project Impacts $\ldots \ldots \ldots \ldots \ldots \ldots \ldots$

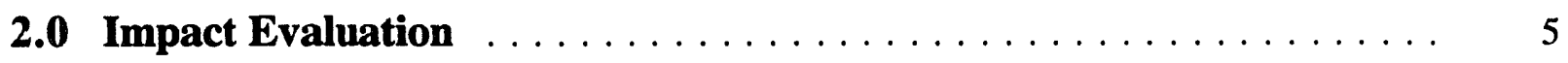

2.1 Energy Savings and Fuel Switching $\ldots \ldots \ldots \ldots \ldots \ldots \ldots$

2.2 Impacts to the Firm $\ldots \ldots \ldots \ldots \ldots \ldots \ldots \ldots \ldots$

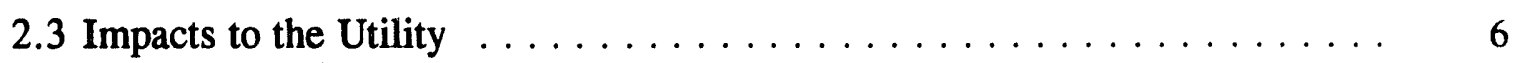

2.4 Real Levelized Costs $\ldots \ldots \ldots \ldots \ldots \ldots \ldots \ldots \ldots \ldots \ldots$

2.4.1 Bonneville Perspective $\ldots \ldots \ldots \ldots \ldots \ldots \ldots \ldots \ldots \ldots$

2.4.2 Regional Perspective $\ldots \ldots \ldots \ldots \ldots \ldots \ldots \ldots \ldots \ldots \ldots$

2.5 Impact Attributable to $\mathrm{E} \$ \mathrm{P} \ldots \ldots \ldots \ldots \ldots \ldots$

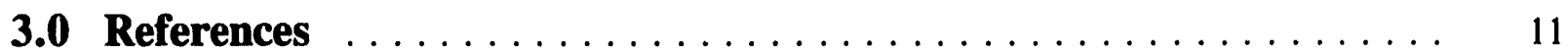

Appendix A - Financial Evaluation Details $\ldots \ldots \ldots \ldots \ldots \ldots \ldots \ldots$

Appendix B - Cover Sheet from Mackenzie Castings' Revised Proposal _. . B.1 


\section{Tables}

2.1 Actual Production Levels and Energy Consumption $\ldots \ldots \ldots \ldots \ldots$

2.2 Installation Costs and Energy Savings $\ldots \ldots \ldots \ldots \ldots \ldots \ldots \ldots \ldots \ldots \ldots \ldots \ldots$

2.3 Levelized Costs at Three Different Production Levels $\ldots \ldots \ldots \ldots \ldots \ldots$ 


\subsection{Introduction}

This report describes Pacific Northwest Laboratory's (PNL's) ${ }^{(a)}$ evaluation of the impact of an energy conservation project installed in May 1993 at Mackenzie Specialty Castings, Incorporated (Mackenzic Castings) in Arlington, Washington. The project at Mackenzie Castings is one in a continuing series of industrial energy conservation projects that have received or will receive acquisition payments from the Bonneville Power Administration (Bonneville) under the Energy \$avings Plan (E\$P) Program, and that are evaluated by PNL.

The E\$P is designed to reduce electrical energy consumption in the industrial sector of Bonneville's service territory. For the Mackenzie Castings project, the acquisition payment options offered under the program were, the lesser of (1) 15c/kilowatt-hour ( $\mathrm{kWh}$ ) saved in the first year, or (2) $80 \%$ of eligible project costs.

The general objective of the impact evaluation was to determine how much electrical energy is saved by the project and at what cost to Bonneville and to the region. In support of this general objective, answers were determined for the following questions:

1. How much silectrical energy is saved annually by the energy conservation project in terms of kilowatt-hours, kilowatt-hours per unit of plant output (unit savings), and average megawatts (aMW)? Also, did any fuel switching result from implementing this project?

2. If the project improved the productivity of the process, did the firm then increase output of the process to take advantage of the productivity improvement? Did the change in output result in a net increase or decrease in energy used by the process? Did the change in output cause changes in output at the firm's other plants in the region?

3. What was the net impact to the serving utility in terms of electrical energy consumption (in kilowatt-hours) from implementing the project?

4. What are the real levelized costs of the project from the perspectives of Bonneville and the region?

5. How much of the project's savings can be attributed solely to the E\$P?

(a) Pacific Northwest Laboratory is operated for the U.S. Department of Energy by Battelle Memorial Institute under Contract DE-AC06-76RLO 1830. 


\subsection{Approach for Impact Evaluation}

Before selecting individual energy conservation projects for evaluation, PNL developed a general impact evaluation methodology (Spanner et al. 1988). The major finding of the methodology development was that in the industrial sector, energy conservation projects must be evaluated on a case-by-case basis. Accordingly, the general methodology consists of a variety of impact evaluation techniques that can be applied to individual projects according to the specific circumstances.

To evaluate the impact of replacing existing power supplies and induction furnaces with new power supplies and furnaces at Mackenzie Castings, four techniques were selected from the general methodology: engineering analysis, financial analysis (see Appendix A), site visit and interview, and review of Mackenzie Casting's submittals, which include the proposal, revised proposal, completion report, vendor's data, technical publications, production levels, energy, consumption and operating schedules. Submetering performed by Mackenzie Castings in accordance with E\$P program requirements was relied upon by PNL to determine the project's impact.

Representatives from PNL visited Mackenzie Castings on October 5, 1993, to view the project firsthand and to interview the owner of the firm.

\subsection{Project Description}

Mackenzie Castings is a jobbing iron foundry which produces grey and ductile iron castings. Mackenzie Castings' primary products are parts made for the aluminum industry. To a lesser degree, Mackenzie Castings produces iron parts for boats, ships, and the Corps of Engineers. Mackenzie Castings melts scrap metal and then uses the sand-casting process to cast custom parts. The foundry consists of three furnaces, two power supplies, a muller, compressors, conveyors, and various auxiliary pumps and equipment.

The energy conservation project at Mackenzie Castings replaced two Pillar Power Paks, 12 and 16 years old, with a combined capacity of $875 \mathrm{~kW}$, with two new and more efficient Ajax Pacer solidstate power supply units with capacities of $750 \mathrm{~kW}$ and $500 \mathrm{~kW}$. The three existing induction furnaces with capacities of $2400 \mathrm{lbs}$ ( 2 furnaces, each $2400 \mathrm{lbs}$ ), and $700 \mathrm{lbs}$ were also upgraded to Ajax coreless induction furnaces with capacities of $3200 \mathrm{lbs}, 2500 \mathrm{lbs}$, and $750 \mathrm{lbs}$. The old power supply and furnace were experiencing difficulty due to cooling methods used previous to 1985 , but were expected to last five more years. 
Mackenzie Castings submitted three documents to Bonneville: a proposal, a revised proposal, and a completion report. The proposal described the energy conservation project and presented Mackenzie Castings's cost and benefit expectations. Included was a calculation of the project's expected simple payback. A revised proposal was submitted after Mackenzie Castings decided to obtain the replacement furnaces from a different vendor. A completion report was submitted to Bonneville after the project was installed and Mackenzie Castings had verified the resulting energy savings. This document listed the actual costs of the project along with a calculation of the energy savings that had been achieved. A copy of the cover sheet from the revised proposal is included in Appendix B.

The total cost to install this project was $\$ 277,110$ and Bonneville paid $\$ 102,551$ for the energy saved. Mackenzie Castings received a loan of \$172,694 from Snohomish County Public Utility District No. 1 (Snohomish County PUD) at $0.98 \%$ interest. The acquisition payment was calculated by multiplying the estimated first year savings in $\mathrm{kWh}$ from the revised proposal by $15 \mathrm{c}(683,677 \mathrm{kWh} *$ $15 \mathrm{c} / \mathrm{kWh}=\$ 102,551)$

\subsection{Summary of Project Impacts}

This E\$P project is expected to save $425,257 \mathrm{kWh} / \mathrm{yr}$ at minimum production, $647,037 \mathrm{kWh} / \mathrm{yr}$ at typical production, and $1,294,074 \mathrm{kWh} / \mathrm{yr}$ at maximum production, or $0.05,0.07$, and $0.15 \mathrm{aMW}$, respectively. This is a savings of $31 \%$ per ton for minimum production and $39 \%$ per ton for typical and maximum production. Over the assumed 15-year life of this project, the levelized cost to Bonneville is $22.9 \mathrm{mills} / \mathrm{kWh}$ at minimum production, $15.1 \mathrm{mills} / \mathrm{kWh}$ at typical production, and 7.5 mills $/ \mathrm{kWh}$ at maximum production ( 1 mill $=1 / 1000$ of a dollar). Cost to the region is $59.1 \mathrm{mills} / \mathrm{kWh}$ at minimum production, $38.8 \mathrm{mills} / \mathrm{kWh}$ at typical production, and $19.4 \mathrm{mills} / \mathrm{kWh}$ at maximum production. These costs are in real 1993 dollars and do not include additional savings that accrue if transmission and distribution losses are considered. The levelized cost to Bonneville, including transmission and distribution losses, is 14.0 mills $/ \mathrm{kWh}$ at typical production and the cost to the region is $36.1 \mathrm{mills} / \mathrm{kWh}$.

Without the acquisition payment from Bonneville and the loan from Snohomish County PUD, this project did not meet Mackenzie Castings' funding criteria; however, it did meet the criteria with the acquisition payment and loan. Therefore, we conclude that it would not have been installed in the absence of the E\$P, and is not a free rider. So all of the impact is attributed to the E\$P. 


\subsection{Impact Evaluation}

The following rection addresses the five major objectives of the impact evaluation, as previously stated in Section 1.0.

\subsection{Energy Savings and Fuel Switching}

1. How much electrical energy is saved annually by the project in terms of kilowatt-hours, kilowatt-hours per unit of plant output, and average megawatts? Also, did any fuel switching result from implementing this project?

\section{Energy Savings}

To verify savings for this project, electricity meter readings were to have been taken for two weeks before and for two weeks after the project was installed. The difference in these readings would have represented the savings over a two-week period. However, Bonneville requested a different methodology using the previous yearly data as a before-installation baseline, and the two-week post-installation data, as the after-installation energy consumption.

Savings were calculated in the completion report by computing a ratio of $\mathrm{kWh}$ consumed to pounds of material produced. The after-installation ratio was subtracted from the before-installation ratio, then multiplied by the production level for the year, which gave a yearly savings in $\mathrm{kWh}$. The previous year and the two-week post-installation data were chosen as a base for typical and maximum production levels, and the quarterly data were chosen as a base for the minimum production level. The methodology and typical production level calculations for the energy savings are as follows:

Method:

$$
\left[\frac{\mathrm{kWh}}{\mathrm{lbs}} \text { (before) }-\frac{\mathrm{kWh}}{\mathrm{lbs}} \text { (after) }\right] \times \text { production level in } \mathrm{lbs} / \mathrm{yr}=\text { Savings in } \mathrm{kWh} / \mathrm{yr}
$$

\section{Typical:}

$$
\left[\frac{1,686,575 \mathrm{kWh}}{3,017,000 \mathrm{lbs}}-\frac{39,931 \mathrm{kWh}}{116,300 \mathrm{lbs}}\right] \times 3,000,000 \mathrm{lbs} / \mathrm{yr}=647,037 \mathrm{kWh} / \mathrm{yr}
$$


PNL obtained more detailed information about production levels, energy consumption, and schedules for the previous year (May 1991 to April 1992), the metering period, the quarter directly after installation (May 1993 - July 1993), and its corresponding quarter for the previous year (May 1992 July 1992). First, Mackenzie Castings provided the actual production data and corresponding energy consumption which are listed in Table 2.1 .

Subsequent discussions with Mackenzie Castings revealed the minimum, typical, and maximum annual production levels to be $1.4,3.0$, and 6.0 millon lbs where minimum, typical, and maximum annual production levels refer to the amount of product produced over the course of a year, not an instantaneous production level. It is unknown what the actual annual production levels will be at Mackenzie over the life of the project, so analysis was done at all three levels. The executive stated that the most likely or typical annual production would be 3.0 million lbs per year. This was based on previous years, incoming orders, and the executive's many years experience in the market. To obtain the energy savings over the whole year, PNL used all three production levels, annual energy consumption, quarterly energy consumption, quarterly production rates, and meter readings to arrive at an estimated yearly electrical energy savings of $425,257 \mathrm{kWh}(0.05 \mathrm{aMW})$ at minimum level, $647,037 \mathrm{kWh}$ $(0.07 \mathrm{aMW})$ at typical level, and $1,294,074 \mathrm{kWh}(0.15 \mathrm{aMW})$ at maximum production level. The savings estimated for the t/pical production level differs from the $683,677 \mathrm{kWh} / \mathrm{yr}$ predicted by the revised project proposal and the $666,732 \mathrm{kWh} / \mathrm{yr}$ projected by the completion report. The reason for the difference with the revised proposal is because the revised proposal assumed a higher production $(17,000 \mathrm{lbs} /$ year higher) and the vendor's energy consumption projection of $3.1 \mathrm{lbs} / \mathrm{kW}$ was a little high. The reason for the difference with the completion report is because the completion report used a higher production (142,000 lbs/yr higher).

Table 2.1. Actual Production Levels and Energy Consumption

\begin{tabular}{|l|r|r|c||}
\hline \multicolumn{1}{|c|}{ Period } & \multicolumn{1}{|c|}{$\begin{array}{c}\text { Metal } \\
\text { Produced } \\
(\mathrm{lb})\end{array}$} & $\begin{array}{c}\text { Energy } \\
\text { Consumed } \\
(\mathrm{kWh})\end{array}$ & $\begin{array}{c}\text { Specific Energy } \\
\text { Consumption } \\
(\mathbf{k W h} / \mathrm{lb})\end{array}$ \\
\hline Previous Year (May 91 - April 92) & $3,017,000$ & $1,686,575$ & .559 \\
Quarterly (May - July 92) & 389,572 & 384,600 & .987 \\
Quarterly (May - July 93) & 286,550 & 195,852 & .683 \\
Two-week Post-installation Metering Period & 116,300 & 39,931 & .343 \\
\hline
\end{tabular}


On a per-ton basis, this project will save $608 \mathrm{kWh} /$ ton at minimum production and $431 \mathrm{kWh} /$ ton for typical and maximum production, which is a reduction of approximately $31 \%$ and $39 \%$, respectively. Note that the savings percentage at minimum production is lower than the savings percentage at typical production, even though the savings per ton are greater at minimum production. This is because iron production at minimal production is much more energy intensive than at typical production. So even though savings per ton are greater at minimum production, the percentage savings are lower. Table 2.2 shows the installation costs and energy savings as reported in the completion report and the impact evaluation.

Table 2.2. Installation Costs and Energy Savings

\begin{tabular}{|l|c|c|}
\hline \multicolumn{1}{|c|}{ Source } & Energy Savings $(\mathrm{kWh})$ & Installation Costs \\
\hline Completion Report & 666,732 & $\$ 277,110$ \\
\hline Impact Evaluation & 647,037 & $\$ 277,110$ \\
\hline
\end{tabular}

\section{Fuel Switching}

Fuel switching to a natural gas furnace was a possibility for Mackenzie Castings. However, because of emissions from the natural gas, additional equipment would have been needed at a greater cost, thus, it was not considered feasible.

\subsection{Impacts to the Firm}

2. If the project improved the productivity of the process, did the firm then increase output of the process to take advantage of the productivity improvement? Did the change in output result in a net increase or decrease in energy used by the process? Did the change in output 
Either the furnace or the molding department could be the limiting factor to Mackenzie Castings' output, depending on the product mix manufactured at the plant. In summary, output at Mackenzie Castings might increase in the future, but it will be the result of changes in market conditions, not the replacement of the furnace. If output does eventually increase, the material produced will consume $431 \mathrm{kWh} /$ ton less electrical energy than it did before the furnace was replaced.

Mackenzie Castings has no other plants in the region, so no impacts will occur at other plants.

\subsection{Impacts to the Utility}

3. What is the net impact to the serving utility in terms of eiectrical energy consumption (in kilowatt-hours) from implementing the project?

Because the project had no cogeneration or other complicating factors, all of the energy savings from this project will be reflected in reduced load at the utility, Snohomish County PUD. The net impact to the serving utility from this project is expected to be a reduction in electrical energy consumption of $647,037 \mathrm{kWh} / \mathrm{yr}$ at typical production levels.

\subsection{Real Levelized Costs}

\section{What are the real levelized costs of the project from the perspectives of Bonneville and the region?}

Real levelized annual costs are used to compare the attractiveness of various projects or investment alternatives. The levelized cost is the annual cost that would be incurred over the life of a project, accounting for the time value of money (see Appendix $\mathbf{A}$ for complete definitions and formula). Levelized costs provide a single figure of merit for compiaring energy conservation alternatives. In addition, levelized costs can be used to compare conservation projects with options for new generating capacity and to optimize the ranking of these options. Levelized costs are calculated from the perspectives of Bonneville and the region (Bonneville, Snohomish County PUD, and Mackenzie Castings combined).

In the industrial sector, it is not possible to accurately predict the life of a project because any number of external factors could cause the project to have longer or shorter iife than expected when it is installed. To allow comparisons of levelized costs among projects installed under the E\$P, all projects 
are assumed by PNL (for evaluation purposes) to have a life of 15 years. Even though some projects will have longer or shorter lives, 15 years is considered a conservative, but likely, life for typical projects in the industrial sector.

\subsubsection{Bonneville Perspective}

To determine the real levelized costs to Bonneville and to the region, we must know the project costs (acquisition payment, capital costs, etc.) and the energy savings, and we must assume a discount rate and project life. With energy savings of $425,257 \mathrm{kWh} / \mathrm{yr}, 647,037 \mathrm{kWh} / \mathrm{yr}$, and $1,294,074$ $\mathrm{kWh} / \mathrm{yr}$, the project's levelized costs from Bonneville's perspective are $22.9 \mathrm{mills} / \mathrm{kWh}$, $15.1 \mathrm{mills} / \mathrm{kWh}$, and $7.5 \mathrm{mills} / \mathrm{kWh}$ (in 1993 dollars). See Appendix A and Table 2.3. Bonneville's levelized costs decrease to $21.3 \mathrm{mills} / \mathrm{kWh}, 14.0 \mathrm{mills} / \mathrm{kWh}$, and $7.0 \mathrm{mills} / \mathrm{kWh}$ when transmission and distribution losses are considered. Including these losses allows for the comparison of conservation resources with generation, which is measured at the point of production rather than at the site of the end user (point of delivery).

The levelized costs calculated in this impact evaluation include the acquisition payment by Bonneville as well as the estimated administrative and evaluation costs associated with this project.

\subsubsection{Regional Perspective}

To calculate the real levelized cost to the region, the costs to Bonneville, Snohomish County PUD, and Mackenzie Castings are combined. The acquisition payment by Bonneville is included as a cost to Bonneville and as a reduction in cost to Mackenzie Castings. This approach is taken because the acquisition payment has federal income tax consequences for the company and, therefore, is not a net zerocost to the region. Snohomish County PUD costs include the opportunity cost of providing a loan to Mackenzie Castings at $\mathbf{0 . 9 8 \%}$ annual percentage rate. The interest rate on the loan accounts for the utility's administration costs for the project.

The calculated, real, levelized costs to the region for acquiring annual energy savings of $425,257 \mathrm{kWh}, 647,037 \mathrm{kWh}$, and 1,294,074 kWh are 59.1 mills/kWh, $38.8 \mathrm{mills} / \mathrm{kWh}$, and $19.4 \mathrm{mills} / \mathrm{kWh}$ saved, respectively. By including transmission and distribution losses, the levelized cost decreases to $55.0 \mathrm{mills} / \mathrm{kWh}, 36.1 \mathrm{mills} / \mathrm{kWh}$, and $18.1 \mathrm{mills} / \mathrm{kWh}$ saved, respectively. 
Table 2.3. Levelized Costs at Three Different Production Levels

\begin{tabular}{|c|c|c|c|c|c|c|}
\hline & \multirow[b]{2}{*}{$\begin{array}{c}\text { Production } \\
\text { Level } \\
\text { (lbs/yr) }\end{array}$} & \multirow[b]{2}{*}{$\begin{array}{l}\text { Annual } \\
\text { Energy } \\
\text { Savings } \\
\text { (kWh) }\end{array}$} & \multicolumn{2}{|c|}{ Bonneville Perspective } & \multicolumn{2}{|c|}{ Regional Perspective } \\
\hline & & & $\begin{array}{c}\text { Real } \\
\text { Levelized } \\
\text { Cost } \\
\text { (mills/kWh) }\end{array}$ & $\begin{array}{l}\text { Real Levelized } \\
\text { Cost Including } \\
\text { Transmission and } \\
\text { Distribution Losses } \\
\text { (mills/kWh) }\end{array}$ & $\begin{array}{c}\text { Real } \\
\text { Levelized } \\
\text { Cost } \\
\text { (mills/kWh) }\end{array}$ & $\begin{array}{l}\text { Real Levelized } \\
\text { Cost Including } \\
\text { Transmission and } \\
\text { Distribution Losses } \\
\text { (mills } / \mathrm{kWh} \text { ) }\end{array}$ \\
\hline At minimum production & $1,400,000$ & 425,257 & 22.9 & 21.3 & 59.1 & 55.0 \\
\hline At typical production & $3,000,000$ & 647,037 & 15.1 & 14.0 & 38.8 & 36.1 \\
\hline At maximum production & $6,000,000$ & $1,294,074$ & 7.5 & 7.0 & 19.4 & 18.1 \\
\hline
\end{tabular}

\subsection{Impact Attributable to E\$P}

\section{How much of the project's impact can be attributed to the E\$P?}

Mackenzie Castings' criterion for selecting plant improvement projects is that, "equipment must pay for itself," but no predetermined payback period is specified. When this project was proposed to Bonneville, it was expected to cost $\$ 277,110$ and result in electrical savings of $\$ 20,678 / y r$ based on usage alone, for a simple payback of about $\mathbf{1 3 . 4}$ years based solely on energy savings. With the acquisition payment from Bonneville, the simple payback was expected to be 6.3 years. Mackenzie Castings' up-front, out-of-pocket cost for the project was $\$ 1,865$, considering the acquisition payment from Bonneville and the loan from Snohomish County PUD.

According to an executive at Mackenzie Castings, the firm realized it would need to replace the power supplies and furnaces within five years. The acquisition payment and the loan made it possible to replace the equipment ahead of schedule and choose the most energy efficient models. This project also results in non-energy savings for Mackenzie Castings. Downtime and maintenance requirements are reduced with the new furnace. Product quality is improved and less down-stream labor is required for grinding and welding. Safety improvements are also attributed to this project.

Mackenzie Castings became aware of the E\$P Program from a newspaper article about another foundry (Sullivan and Spanner 1992) that had participated, at which time the owner realized that there might be a way to replace the furnaces at Mackenzie Castings which the firm could not have otherwise afforded to do. 
Considering the facts presented above, we conclude that this project would not have been implemented without the acquisition payment from Bonneville and that all of the project's impact can be attributed to the E\$P. 


\subsection{References}

Spanner, G. E., D. R. Brown, D. R. Dixon, B. A. Garrett, R. W. Reilly, J. M. Roop, and S. A. Weakley. 1988. Potential Techniques for Evaluating the Impact of Industrial Energy Conservation Projects under Bonneville's Energy \$avings Plan. Letter Report. PNL-6628, Pacific Northwest Laboratory, Richland, Washington.

Sullivan G. P., and G. E. Spanner. 1992. Impact Evaluation of an Energy Savings Plan Project at Sather Manufacturing. Letter Report. PNL-8426, Pacific Northwest Laboratory, Richland, Washington. 
Appendix A

Financial Evaluation Details 


\section{Appendix A}

\section{Financial Evaluation Details}

\section{A.1 Definitions}

Real Levelized Cost - A single figure of merit that expresses the cost per unit of benefit (in this case, energy savings), accounting for the time value of money. This annualized cost (not the "adjusted system real levelized cost") would be constant over the entire project life. An infinite number of cash flow scenarios (costs incurred at different times in the project life) could result in the same annualized cost.

Real Levelized Cost to Bonneville Power Administration (Bonneville) - The annualized costs to Bonneville, direct and indirect, per unit of energy saved by the energy conservation project. Costs included are the acquisition payment and the program administrative costs, as well as the costs to evaluate the impact of this project.

Real Levelized Cost to the Region - The sum of annualized costs to Bonneville, and Snohomish County PUD and Mackenzie Castings per unit of energy saved by the energy conservation project. This would include the same costs to Bonneville as listed above, as well as the initial capital and ongoing incremental production costs to the firm. Any non-electrical savings that result from the project are not considered in this analysis.

\section{A.2 Real Levelized Cost Formula}

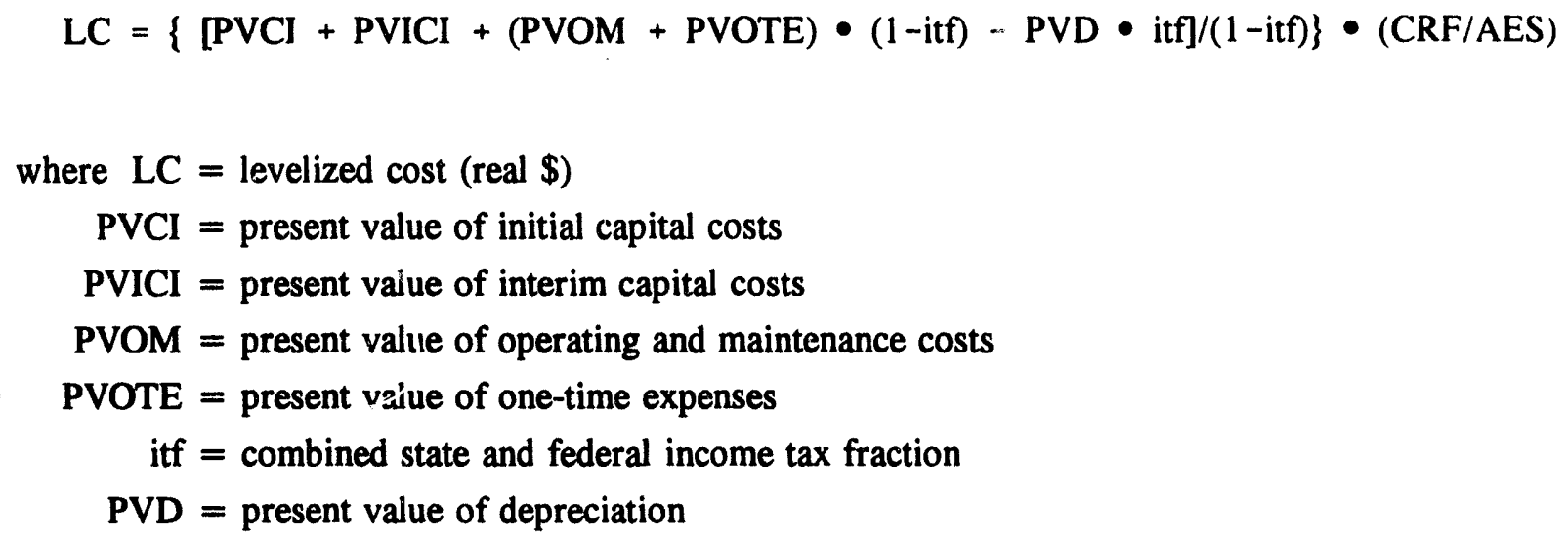


CRF = capital recovery factor (spreads the costs over the project life in real-dollar terms) $\mathrm{AES}=$ annual energy savings $(\mathrm{kWh} / \mathrm{yr})$.

\section{A.3 General Assumptions}

The following general assumptions were made in the real levelized cost calculations:

1. All cash flows are expressed in nominal terms (with inflation) and are discounted to present value at a nominal discount rate of $7.12 \%$ (combines a real discount rate of $3.0 \%$ and an inflation rate of $4.0 \%$ ). The costs are annualized over the life of the project using the capital recovery factor at a real discount rate of $3.0 \%$, resulting in real levelized costs.

2. Annual energy savings ( $\mathrm{kWh} / \mathrm{yr})$ are constant over the 15 -year life of the project. This assumes no loss in efficiency of the equipment with ime.

3. Transmission and distribution losses equal $7.5 \%$, increasing the energy savings at the source (point of generation) by a corresponding $7.5 \%$.

4. In the regional cost calculation, the acquisition payment from Bonneville is treated as a cost to Bonneville and, at the same time, a cash inflow to Mackenzie Castings rather than a net-zero cost. This is done because Mackenzie Castings will incur a tax liability from the acquisition payment, thus incurring a net cost to the region.

5. The nominal loan rate used for Snohomish County PUD calculations was $8 \%$. Snohomish County PUD nominal loan rate to Mackenzie Castings was $0.98 \%$. Both loans were assumed to be equal series payments over 10 years. 


\section{A.4 Bonneville Levelized Cost Calculations for Minimum Production}

Input: one-time expenses

$\begin{array}{ll}\text { Acquisition payment paid (year } 1) & =\$ 102,551 \\ \text { Administrative and evaluation costs (years } 0 \text { and } 1) & =\$ 21,200 \\ \text { Tax rate } & =0 \% \\ \text { Annual energy savings } & =425,257 \mathrm{kWh} \\ \text { tput: levelized cost } & =22.9 \text { miiis } / \mathrm{kWh}\end{array}$

\section{A.5 Bonneville Levelized Cost Calculations for Typical Production}

Input: one-time expenses
Acquisition payment paid (year 1)
$=\$ 102,551$
Administrative and evaluation costs (years 0 and 1) $=\$ 21,200$
Tax rate
$=0 \%$
Annual energy savings
$=647,037 \mathrm{kWh}$
Output: levelized cost
$=15.1 \mathrm{mills} / \mathrm{kWh}$

\section{A.6 Bonneville Levelized Cost Calculations for Maximum Production}

Input: one-time expenses

Acquisition payment paid (year 1)

$=\$ 102,551$

Administrative and evaluation costs (years 0 and 1$)=\$ 21,200$

Tax rate

$=0 \%$

Annual energy savings

$=1,294,074 \mathrm{kWh}$

Output: levelized cost

$=7.5 \mathrm{mills} / \mathrm{kWh}$ 


\section{A.7 Regional Levelized Cost Calculations (Bonneville + Snohomish County PUD + Mackenzie Castings) for Minimum Production}

\section{A. Mackenzie Castings}

Input:

Initial capital (year 0)
Equipment
$=\$ 277,110$
Loan from Snohomish County PUD $(0.98 \%, 10$ years $)=(\$ 172,693)$
One-time expenses (revenues - year 1)
Acquisition payment received
$=(\$ 102,551)$
Tax rate
$=34 \%$
Project life
$=15$ years
Depreciation
$=7$ years
Annual energy savings
$=425,257 \mathrm{kWh}$
$=25.8 \mathrm{mills} / \mathrm{kWh}$

Output: levelized cost

B. Snohomish County PUD

Input: expenses

Loan amount

$=\$ 172,693$

Interest rate paid by Snohomish County PUD

$=8 \%$

Interest rate paid by Mackenzie Castings

$=0.98 \%$

Tax rate

$=0 \%$

Annual energy savings

$=425,257 \mathrm{kWh}$

Output: levelized cost

$=10.4 \mathrm{mills} / \mathrm{kWh}$

C. Regional levelized cost $=$ Bonneville levelized cost + Mackenzie

Castings levelized cost + Snohomish County PUD levelized cost

$=22.9$ mills $/ \mathrm{kWh}+25.8$ mills $/ \mathrm{kWh}+10.4$ mills $/ \mathrm{kWh}$

$=59.1 \mathrm{mills} / \mathrm{kWh}$

A.4 


\section{A.8 Regional Levelized Cost Calculations (Bonneville + Snohomish County PUD + Mackenzie Castings) for Typical Production}

\section{A. Mackenzie Castings}

Input:

Initial capital (year 0)

Equipment

$=\$ 277,110$

Loan from Snohomish County PUD $(0.98 \%, 10$ years $)=(\$ 172,693)$

One-time expenses (revenues - year 1)

Acquisition payment received

Tax rate

$=34 \%$

Project life

$=15$ years

Depreciation

$=7$ years

Annual energy savings

$=647,037 \mathrm{kWh}$

Output: levelized cost

$=17.0 \mathrm{mills} / \mathrm{kWh}$

B. Snohomish County PUD

Input: expenses

Loan amount

$=\$ 172,693$

Interest rate paid by Snohomish County PUD

$=8 \%$

Interest rate paid by Mackenzie Castings

$=0.98 \%$

Tax rate

$=0 \%$

Annual energy savings

$=647,037 \mathrm{kWh}$

Output: levelized cost

$=6.8 \mathrm{mills} / \mathrm{kWh}$

C. Regional levelized cost $=$ Bonneville levelized cost + Mackenzie

Castings levelized cost + Snohomish County PUD levelized cost

$=15.1 \mathrm{mills} / \mathrm{kWh}+17.0 \mathrm{mills} / \mathrm{kWh}+6.8 \mathrm{mills} / \mathrm{kWh}$

$=38.8 \mathrm{mills} / \mathrm{kWh}$ 


\section{A.9 Regional Levelized Cost Calculations (Bonneville + Snohomish County PUD + Mackenzie Castings) for Maximum Production}

\section{A. Mackenzie Castings}

Input:

Initial capital (year 0)
Equipment
$=\$ 277,110$
Loan from Snohomish County PUD $(0.98 \%, 10$ years $)=(\$ 172,693)$

One-time expenses (revenues - year 1)

Acquisition payment received

$=(\$ 102,551)$

Tax rate

$=34 \%$

Project life

$=15$ years

Depreciation

$=7$ years

Annual energy savings

$=1,294,074 \mathrm{kWh}$

Output: levelized cost

$=8.5 \mathrm{mills} / \mathrm{kWh}$

B. Snohomish County PUD

Input: expenses

Loan amount

$=\$ 172,693$

Interest rate paid by Snohomish County PUD

$=8 \%$

Interest rate paid by Mackenzie Crstings

$=0.98 \%$

Tax rate

$=0 \%$

Annual energy savings

$=1,294,074 \mathrm{kWh}$

Output: levelized cost

$=3.4 \mathrm{mills} / \mathrm{kWh}$

C. Regional levelized cost $=$ Bonneville levelized cost + Mackenzie

Castings levelized cost + Snohomish County PUD levelized cost

$$
\begin{aligned}
& =7.5 \text { mills } / \mathrm{kWh}+8.5 \text { mills } / \mathrm{kWh}+3.4 \mathrm{mills} / \mathrm{kWh} \\
& =19.4 \mathrm{mills} / \mathrm{kWh}
\end{aligned}
$$




\section{A.10 Levelized Cost Allowing for Transmission and Distribution Losses}

Input: transmission and distribution losses $=7.5 \%$

Method:

$\left[\frac{\text { Levelized Cost }}{1.075}\right]=$ Levelized Cost Allowing for Transmission and Distribution Losses

Typical:

$\left[\frac{38.8 \text { mills } / \mathrm{kWh}}{1.075}\right]=36.1 \mathrm{mills} / \mathrm{kWh}$ 
Table A.1. Summary of Levelized Costs

\begin{tabular}{|c|c|c|c|c|c|c|}
\hline \multirow[b]{2}{*}{ Cost Perspective } & \multicolumn{3}{|c|}{$\begin{array}{l}\text { Ignoring Transmission } \\
\text { and Distribution Losses }\end{array}$} & \multicolumn{3}{|c|}{$\begin{array}{l}\text { Allowing for Transmission } \\
\text { and Distribution Losses }\end{array}$} \\
\hline & $\begin{array}{l}\text { Minimum } \\
\text { Production } \\
\text { (mills/kWh) }\end{array}$ & $\begin{array}{c}\text { Typical } \\
\text { Production } \\
\text { (mills/kWh) }\end{array}$ & $\begin{array}{l}\text { Maximum } \\
\text { Production } \\
\text { (mills/kWh) }\end{array}$ & $\begin{array}{l}\text { Minimum } \\
\text { Production } \\
\text { (mills/kWh) }\end{array}$ & $\begin{array}{c}\text { Typical } \\
\text { Production } \\
\text { (mills/kWh) }\end{array}$ & $\begin{array}{l}\text { Maximum } \\
\text { Production } \\
\text { (mills/kWh) }\end{array}$ \\
\hline Bonneville & 22.9 & 15.1 & 7.5 & 21.3 & 14.0 & 7.0 \\
\hline Snohomish County PUD & 10.4 & 6.8 & 3.4 & 9.6 & 6.3 & 3.2 \\
\hline Mackenzie Castings & 25.8 & 17.0 & 8.5 & 24.0 & 15.8 & 7.9 \\
\hline Region & 59.1 & 38.8 & 19.4 & 55.0 & 36.1 & 18.1 \\
\hline
\end{tabular}




\section{Appendix B}

Cover Sheet from Mackenzie Castings' Revised Proposal 

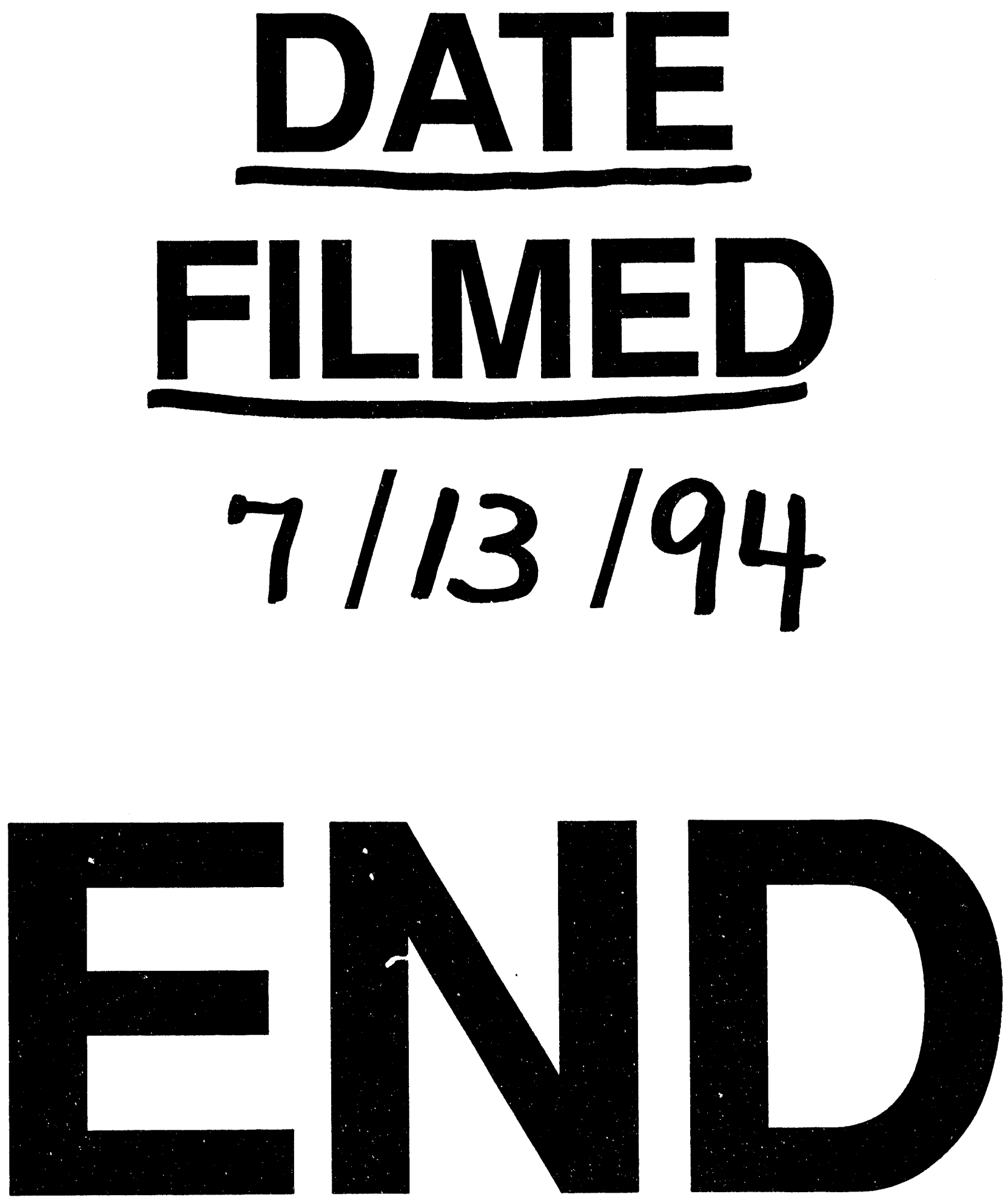
